bifokale briller og progressive briller. For progressive briller finnes det flere kategorier brilleglassløsninger. Grovt kan en skille mellom «vanlige» progressive glass og «dataprogressive» glass. For mange vil en vanlig progressiv brille fungere godt for både mobiltelefonog nettbrettbruk. Slike briller er imidlertid sjelden en god løsning for mer tradisjonelle dataarbeidsplasser. Her er det ofte behov for en mer skreddersydd progressiv løsning med et større område i glasset med skarpt fokus for skjermavstanden. Rådet som gis om briller i artikkelen burde heller ha vært: «Bruk riktig brille!» Like viktig er det at man ved synsundersøkelse hos optiker eller øyelege legger frem sine synsmessige utfordringer og behov, slik at optimale brilleløsninger kan prøves ut og diskuteres. Hva som kan være synsmessige utfordringer er belyst mer i detalj i Nyléns bok «Syn och belysning i arbetslivet» (2). Her skrives det også litt mer om brilleglassløsninger.

Muskelplager og synsproblematikk ved omfattende skjermbruk kan imidlertid ha mange og multifaktorielle årsaker. Selv om Arbeidstilsynets veiledning om arbeid ved dataskjermer først og fremst gjelder bruk av stasjonære datamaskiner (3), er mange av rådene som gis også gode for annen type skjermbruk. Dette gjelder tiltak for å sikre optimale synsforhold, god belysning, og unngå reflekser i skjermen og blending. Det gis også råd om hyppige pauser i skjermarbeidet. Innenfor dette fagfeltet, som nå ofte betegnes visuell ergonomi, foregår det mye forskning. I denne sammenheng kan det nevnes at nr 3/2014 av tidsskriftet Work var et temanummer nettopp om Visual Ergonomics. En av artiklene gir en introduksjon til denne relativt nye ergonomitematikken (4).

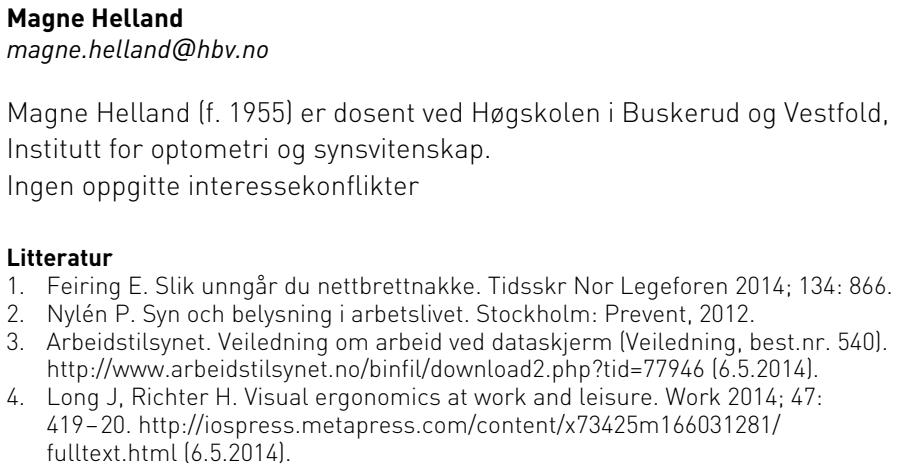

\section{Re: Ytringsfrihed burde funnet sted}

Ole Kristian Losvik har skrevet en fin artikkel med viktig innhold (1). Det kan lett begås overtramp i lojalitetens navn når det gjelder det å kunne ytre seg fritt. Man må aldri slutte å gi tilbakemeldinger og ytre seg, men vi er farlig nær der nå. Byråkratiet styrer for mye, også innenfor helsevesenet!

\section{Kolbein Fremmersvik}

kolfre@sthf.no

Kolbein Fremmersvik (f. 1976) er spesialfysioterapeut ved Notodden sykehus - Sykehuset Telemark.

Ingen oppgitte interessekonflikter

Litteratur

1. Losvik OK. Ytringsfrihed burde funnet Sted. Tidsskr Nor Legeforen 2014; 134: 818.

\section{Re: Ytringsfrihed burde funnet sted}

Legers ytringsfrihet er et viktig tema (1)! Jeg tror dessverre ikke mye vil endre seg hvis ikke flere leger får faste stillinger. Det blir en ekstra høy terskel for å si i fra om kritikkverdige forhold så lenge man er avhengig av å få fornyet et vikariat for å beholde jobben. Pasientene blir den lidende part, og derfor burde det absolutt være i folks interesse at leger i større grad sikres fast ansettelse.

\section{Ingrid Hokstad}

ihokstad@gmail.com

Ingrid Hokstad (f. 1981) er lege.

Ingen oppgitte interessekonflikter

Litteratur

1. Losvik OK. Ytringsfrihed burde funnet Sted. Tidsskr Nor Legeforen 2014; 134 818.

\section{Re: Ensidig om nakkesleng fra Høyesterett}

En del av kritikken Sjaastad \& Hesselberg kommer med i denne artikkelen er for privat og lite eksplisitt til at den kan besvares (1). Jeg har kommentert kritikk mot denne dommen i Tidsskriftet tidligere (2). Artikkelen gir imidlertid en velkommen mulighet til å kommentere innvendinger mot de såkalte Litauen-studiene som man stundom får presentert muntlig, men som vel aldri er formulert skriftlig.

Disse studiene ble utført for å påvise om det kunne være en statistisk sammenheng mellom påkjørsel bakfra og påfølgende nakkeog hodesmerter. Sjaastad \& Hesselberg er svært kritiske til at man ut fra politiprotokoller inkluderte bilførere som hadde vært involvert i slike ulykker, og det virker som de i fullt alvor mener man heller burde ha inkludert skadede som selv har «oppsøkt helsevesenet og dermed blitt definert som pasient». Dette viser at de ikke har forstått hovedstyrken ved Litauen-studiene, nemlig at man har inkludert kohortene utelukkende ut fra om de har eller ikke har vært eksponert for den antatte årsaksmekanismen. Dette er en allment akseptert forutsetning for denne typen studier: «At the time exposure status is defined, all potential subjects must be free from the disease under investigation» (3).

Videre er det i denne saken neppe et godt argument at studiene inkluderte et flertall av menn som var bilførere, fordi saken nettopp gjaldt en mann som satt bak rattet da kollisjonen inntraff. Påstandene om at svarene var upålitelige fordi undersøkelsen var basert på spørreskjema i brev, og svarene farget av befolkningens frykt for myndighetene i et postkommunistisk Litauen, virker lite plausible. Prevalensene av hodepine som ble funnet både $\mathrm{i}$ whiplash-gruppen og kontrollgruppen likner veldig på hodepineprevalens rapportert fra Vest-Europa, og de samsvarer godt med tallene man finner i en hodepineepidemiologisk studie utført i Kaunas i 2008-2009 (del av Eurolight - en stor europeisk studie), utført gjennom personlig intervju med spesialopplærte litauiske medisinstudenter (4).

Sjaastad \& Hesselberg gjør det enkelt for seg selv når de hevder at det kun er to muligheter for å forklare slike plager: enten organisk årsak eller ønske om økonomisk kompensasjon. Innenfor en biopsykososial forståelsesramme eksisterer en rekke andre mulige forklaringer. De sakkyndige i denne saken la en slik forståelsesmodell til grunn, og dette er også det synet som er anbefalt i SMMrapporten om nakkesleng fra 2000 (5), som ble skrevet av et bredt panel av fagpersoner med ulik bakgrunn.

\section{Lars Jacob Stovner}

lars.stovner@ntnu.no

Lars Jacob Stovner (f. 1953) er professor ved Institutt for nevromedisin, Norges teknisk-naturvitenskapelige universitet.

Oppgitte interessekonflikter: Forfatter har i 2013 mottatt honorar for foredrag om nakkesleng i Personskadeforbundet.

\section{Litteratur}

1. Sjaastad O, Hesselberg JP. Ensidig om nakkesleng fra Høyesterett. Tidsskr Nor Legeforen 2014; 134: 721-4.

2. Stovner LJ. Høyesterettsdommen er korrekt. Tidsskr Nor Legeforen 2012; 132: $11-2$. 